\title{
Loss of $\alpha 7$ Nicotinic Receptors Enhances $\beta$-Amyloid Oligomer Accumulation, Exacerbating Early-Stage Cognitive Decline and Septohippocampal Pathology in a Mouse Model of Alzheimer's Disease
}

\author{
Caterina M. Hernandez, ${ }^{1}$ Rakez Kayed, ${ }^{1}$ Hui Zheng, ${ }^{2}$ J. David Sweatt, ${ }^{3}$ and Kelly T. Dineley ${ }^{1}$ \\ ${ }^{1}$ Department of Neurology, Mitchell Center for Neurodegenerative Diseases, University of Texas Medical Branch, Galveston, Texas 77555, ${ }^{2} \mathrm{Huffington}$ \\ Center on Aging, Human and Molecular Genetics, Baylor College of Medicine, Houston, Texas 77030, and ${ }^{3}$ Department of Neurobiology, University of \\ Alabama at Birmingham, Birmingham, Alabama 35294
}

\begin{abstract}
Early Alzheimer's disease (AD) is marked by cholinergic hypofunction, neuronal marker loss, and decreased nicotinic acetylcholine receptor (nAChR) density from the cortex and hippocampus. $\alpha 7 \mathrm{nAChRs} \mathrm{expressed} \mathrm{on} \mathrm{cholinergic} \mathrm{projection} \mathrm{neurons} \mathrm{and} \mathrm{target} \mathrm{regions}$ have been implicated in neuroprotection against $\beta$-amyloid $(\mathrm{A} \beta)$ toxicity and maintenance of the septohippocampal phenotype. We tested the role that $\alpha 7 \mathrm{nAChRs}$ perform in the etiology of early AD by genetically deleting the $\alpha 7 \mathrm{nAChR}$ subunit from the Tg2576 mouse model for $\mathrm{AD}$ and assessing animals for cognitive function and septohippocampal integrity. Thus, Tg2576 mice transgenic for mutant human amyloid precursor protein (APP) were crossed with $\alpha 7 \mathrm{nAChR}$ knock-out mice (A7K0) to render an animal with elevated A $\beta$ in the absence of $\alpha 7$ nAChRs (A7KO-APP). We found that learning and memory deficits seen in 5-month-old APP mice are more severe in the A7KO-APP animals. Analyses of animals in early-stage preplaque cognitive decline revealed signs of neurodegeneration in A7KOAPP hippocampus as well as loss of cholinergic functionality in the basal forebrain and hippocampus. These changes occurred concomitant with the appearance of a dodecameric oligomer of $\mathrm{A} \beta$ that was absent from all other genotypic groups, generating the hypothesis that increased soluble oligomeric A $\beta$ may underlie additional impairment of A7KO-APP cognitive function. Thus, $\alpha 7 \mathrm{nAChRs} \mathrm{in} \mathrm{a} \mathrm{mouse}$ model for early-stage $\mathrm{AD}$ appear to serve a neuroprotective role through maintenance of the septohippocampal cholinergic phenotype and preservation of hippocampal integrity possibly through influences on $\mathrm{A} \beta$ accumulation and oligomerization.
\end{abstract}

\section{Introduction}

In early Alzheimer's disease $(\mathrm{AD})$, there is impairment in hippocampus-based episodic memory that is improved through enhancement of cholinergic transmission, indicating that hypoactivity of septohippocampal projections underlie the earliest AD symptomatology (Riekkinen et al., 1987), which appear to be via reductions in choline acetyltransferase (ChAT) activity as well as depletion of nicotinic acetylcholine receptors (nAChRs) (Perry et al., 1978; Banerjee et al., 2000; Pappas et al., 2000).

The $\alpha 7$ subtype of $\mathrm{nAChR}$ is expressed by basal forebrain cholinergic projection neurons and within the hippocampus

Received Sept. 9, 2009; revised Nov. 21, 2009; accepted Dec. 11, 2009.

This work was supported by funds from the Alzheimer's Association, the John Sealy Memorial Endowment for Biomedical Research, and a kind gift from Jerry and Winkie Mohn to (K.T.D.), funds from the National Institute of Neurological Disorders and Stroke, the National Institute of Mental Health, the American Health Assistance Foundation, and the Evelyn F. McKnight Foundation (J.D.S.), National Institutes of Health Grants R01 NS40039 and R01 AG20670 (H.Z.), and the American Psychological Association/National Institute of Mental Health (C.M.H.). We thank Duy Bui, Angela Chang, Dale Hogan, Kenneth J. O'Riordan, Urmi Sengupta, and Wei Song for their expert technical assistance.

This article is freely available online through the J Neurosci Open Choice option.

Correspondence should be addressed to Dr. Kelly T. Dineley, Department of Neurology, University of Texas Medical Branch, Galveston, TX 77555-0616. E-mail: ktdinele@utmb.edu.

DOI:10.1523/JNEUROSCI.5038-09.2010

Copyright $\odot 2010$ the authors $\quad 0270-6474 / 10 / 302442-12 \$ 15.00 / 0$
(Hunt and Schmidt, 1978; Fabian-Fine et al., 2001; Azam et al., 2003). Several studies have demonstrated that $\alpha 7 \mathrm{nAChR}$ activation attenuates $\beta$-amyloid (A $\beta$ ) toxicity; in vivo, $\alpha 7 \mathrm{nAChRs} \mathrm{have}$ been shown to maintain the septohippocampal cholinergic phenotype, suggesting that $\alpha 7 \mathrm{nAChR}$ activation represents a useful therapeutic strategy for AD (Jonnala and Buccafusco, 2001; Kihara et al., 2001, 2004; Li et al., 2005; Ren et al., 2007). However, this view is confounded by the fact that $\alpha 7 \mathrm{nAChRs}$ and $\mathrm{A} \beta$ peptides have been shown to interact in vitro and in vivo, including human postmortem AD brain (Dineley, 2007; Wang et al., 2009). Furthermore, recent work suggests that an $\alpha 7 \mathrm{nAChR}-\mathrm{A} \beta$ interaction in aged $\mathrm{AD}$ mouse models may exacerbate their pathological features (Ren et al., 2007; Soderman et al., 2008; Dziewczapolski et al., 2009). The role of $\alpha 7 \mathrm{nAChRs}$ in the pathology of preplaque $\mathrm{AD}$ when early cognitive decline is underway has yet to be directly tested.

In this study, we tested the hypothesis that $\alpha 7 \mathrm{nAChRs}$ are neuroprotective during early-stage $\mathrm{AD}$ by investigating the effects of $\alpha 7 \mathrm{nAChR}$ gene deletion on cognitive function and septohippocampal integrity in the Tg2576 [amyloid precursor protein (APP)] transgenic animal model for AD. In addition to $\mathrm{A} \beta$ overproduction and accumulation, this animal model exhibits early-onset ( 5 months of age) and progressive memory defi- 
cits, impaired synaptic plasticity, and alterations of several biochemical markers (Hsiao et al., 1996; Dineley et al., 2001, 2002a; Apelt et al., 2002; Westerman et al., 2002; Spires et al., 2005; Jacobsen et al., 2006). However, cholinergic hypofunction and marked hippocampal neurodegeneration are noticeably absent (Apelt et al., 2002; Stein and Johnson, 2002; Lüth et al., 2003; Wenk et al., 2004; Watanabe et al., 2009).

Whereas $\alpha 7$ nAChR knock-out (A7KO) mice neither show cognitive deficits nor exhibit morphological CNS abnormalities, we found that cognitive deficits seen in 5-month-old APP transgenic mice are more severe when $\alpha 7 \mathrm{nAChR}$ receptors are absent (A7KO-APP) (Orr-Urtreger et al., 1997; Paylor et al., 1998). Biochemical analyses on 5-month-old A7KO-APP revealed significant reduction in hippocampal and basal forebrain ChAT activity and loss of hippocampal neurons and markers; stereological analyses indicated more pronounced loss of hippocampal pyramidal neurons and volume loss compared with APP mice. These observations were concomitant with the appearance of $\sim 56 \mathrm{kDa}$ soluble $\mathrm{A} \beta$ oligomers in the hippocampus of A7KO-APP mice, which may underlie the additional impairment of cognitive function in these mice. Thus, $\alpha 7 \mathrm{nAChRs}$ in a model of early-stage AD appear to serve a neuroprotective role through maintenance of the septohippocampal cholinergic phenotype and preservation of hippocampal integrity possibly through influences on $\mathrm{A} \beta \mathrm{accu}-$ mulation and oligomerization.

\section{Materials and Methods}

Chemicals. Unless otherwise stated, all reagents were purchased from Sigma-Aldrich.

Antibodies for immunoblot. The antibodies used for immunoblotting included the following: synaptophysin (1:1000; catalog \#101002; Synaptic Systems), vesicular acetylcholine transporter (VAChT) (1:200; catalog \#sc-7716; Santa Cruz Biotechnology), ChAT (1:200; catalog \#sc-20672; Santa Cruz Biotechnology), $\beta$-actin (1:10,000; catalog \#A5441; SigmaAldrich), MAP2 (1:2000; catalog \#AB5622; Millipore Corporation), extracellular signal-regulated kinase (ERK) and phospho-ERK (1:5000; catalog \#9102 and \#9101, respectively; Cell Signaling Technologies), and 4G8 (1:5000; catalog \#SIG-39200; Covance). Secondary antibodies were purchased from Cell Signaling Technologies (anti-rabbit, catalog \#7074; anti-mouse, catalog \#7076) and Santa Cruz Biotechnology (anti-goat, catalog \#sc-2350). APP C-terminal antibodies were a kind gift from Drs. Christopher Eckman (Mayo Clinic, Jacksonville, FL) and Kumar Sambamurti (Medical University of South Carolina, Charleston, SC). Antibodies against soluble, fibrillar, oligomeric amyloids (OC; 1:5000) were a kind gift from Dr. Rakez Kayed.

Animal subjects. We studied mice that overproduce A $\beta$ (APP) and lack $\alpha 7$ nAChRs (A7KO). The A7KO-APP genotype was generated by first crossing Tg2576 (50\% C57BL/6, 50\% SJL) with mice heterozygous for the null mutation in $\alpha 7$ (congenic C57BL/6) and then crossing the appropriate heterozygous $\mathrm{F} 1$ mice to each other. Genotype of each animal was determined by PCR of genomic DNA isolated from tail biopsy material obtained at weaning (Orr-Urtreger et al., 1995, 1997; Hsiao et al., 1996). The nomenclature for the mouse models generated in this study is designated WT (wild-type), A7KO, APP, and A7KO-APP.

Behavioral analysis was performed on 5 -month-old littermate mice (WT, $n=15$; A7KO, $n=6$; APP, $n=15$; A7KO-APP, $n=9$ ) and 3 -month-old mice (WT, $n=4$; A7KO-APP, $n=3$ ). For biochemistry, 5or 12-month-old animals were analyzed; three to six animals of each genotype were used. For histological and stereological analyses, both 3to 5-month-old and 16- to 19-month-old mice were analyzed; six animals of each genotype were used.

Mice were housed three to five per cage in a room with a $12 \mathrm{~h} \mathrm{light/dark}$ cycle (lights on at 6:00 A.M.) with access to food and water ad libidum. Male and female mice were used, all bred in-house. The University of Texas Medical Branch operates in compliance with the following: the United States Department of Agriculture Animal Welfare Act (Public
Law 89-544) as amended by PL91-579 (1970), PL94-279 (1976), and 45 CRF37618 (June 30, 1980); the Health Research Extension Act of 1985 (Public Law 99-158); the Public Health Service Policy on Humane Care and Use of Laboratory Animals; and the Guide for Care and Use of Laboratory Animals (Department of Health, Education, and Welfare, National Institutes of Health, Publication 85-23 revised 1985).

Behavioral analysis. Animals were evaluated for general health, sensory perceptiveness, activity level, as well as object recognition and associative learning performance at 5 months of age according to our previously published methods (Dineley et al., 2002b, 2007; Taglialatela et al., 2009) with some modifications as described. The experimenter was blind to the genotype of the subjects. For detailed methods of additional behavioral testing, see supplemental data (available at www.jneurosci.org as supplemental material).

Novel object recognition. Each mouse was habituated to an empty novel object recognition (NOR) open-field box for two 10-min test sessions $24 \mathrm{~h}$ apart. Twenty-four hours after the last habituation session, mice were subjected to training in a 10 min session of exposure to two identical, nontoxic objects (metal or hard plastic items) in the open-field box. The time spent exploring each object was recorded using ObjectScan (Clever Sys. Inc.); an area $2 \mathrm{~cm}^{2}$ surrounding the object is defined such that nose entries within $2 \mathrm{~cm}$ of the object was recorded as time exploring the object. After the training session, the animal was returned to its home cage. After a retention interval of $24 \mathrm{~h}$, the animal was returned to the arena in which two objects, one identical to the familiar object but previously unused (to prevent olfactory cues and prevent the necessity to wash objects during experimentation) and one novel object. The animal was allowed to explore for $10 \mathrm{~min}$, during which the amount of time exploring each object was recorded. Objects were randomized and counterbalanced across animals. Animals that spent $<7$ s exploring the objects during the 10 min test session were omitted from analysis (de Bruin and Pouzet, 2006). Objects and arenas were thoroughly cleaned with $70 \%$ isopropanol between trials.

Fear conditioning. The two-pairing paradigm for fear conditioning training consists of placing the animal in the fear conditioning apparatus (Med Associates) for a total of $7 \mathrm{~min}$. Animals were left free to explore for $3 \mathrm{~min}$, and then a $30 \mathrm{~s}$ acoustic conditioned stimulus (CS) (white noise, $80 \mathrm{~dB}$ ) was delivered. At the end of the CS, a 2 s shock unconditioned stimulus (US) (1.0 mA) was applied to the grid floor. The CS-US pairing was delivered again at the 5 min mark. Fear learning testing was performed $24 \mathrm{~h}$ after training. To evaluate contextual fear learning, the animals were returned to the training context, and freezing behavior was scored for $5 \mathrm{~min}$. To evaluate cued fear learning, the animals were placed in a different context (novel odor, lighting, cage floor, and visual cues) at least $4 \mathrm{~h}$ after contextual testing. Baseline behavior was scored for $3 \mathrm{~min}$, and then the CS was presented for a period of $3 \mathrm{~min}$. Freezing behavior was scored with Actimetrics FreezeFrame software captured with realtime digital video. Data are expressed as percentage freezing in each $60 \mathrm{~s}$ epoch or a mean of these five epochs.

Animal tissue preparation. After completion of behavioral analyses, mice were killed by decapitation or transcardial perfusion under anesthesia. Brains were removed, immediately placed into ice-cold $0.9 \%$ $\mathrm{NaCl}$, and then stored at $-70^{\circ} \mathrm{C}$. For transcardial perfusion, mice were anesthetized with avertin and transcardially perfused with PBS, $\mathrm{pH}$ 7.4, followed by $4 \%(\mathrm{w} / \mathrm{v})$ paraformaldehyde fixative in PBS, $\mathrm{pH}$ 7.4. Whole brains were removed and postfixed overnight at $4^{\circ} \mathrm{C}$. For young mice (3-5 months), whole brains were stored in $70 \%$ ethanol, paraffin embedded, and horizontally sectioned at $10 \mu \mathrm{m}$. For aged $(16+$ months old $)$ mice, whole brains were sucrose protected, cut into $1 \mathrm{~mm}$ blocks, and coronally sectioned from the fornix through the entire hippocampus at $25 \mu \mathrm{m}$. Sections were deparaffinized (if needed) and rehydrated and then stained with $0.5 \%$ cresyl violet or immunostained with anti-neuronal nuclear antigen $(\mathrm{NeuN})$; in the case of aged samples, sections were also stained with $0.2 \%$ Congo Red (Paxinos and Watson, 2003; Wilcock et al., 2006). For anti-NeuN immunostaining, all sections underwent heated antigen retrieval with $0.01 \mathrm{~m}$ sodium citrate, $\mathrm{pH} 6.0$, blocking with $5 \%$ $(\mathrm{v} / \mathrm{v})$ normal goat serum in PBS, and overnight incubation with antiNeuN (1:2000; catalog \#MAB377; Millipore Corporation). Anti-NeuN was detected using the ABC method (Universal ABC kit; Vector Lab- 
oratories) and streptavidin-cyanine 3 (1:400; catalog \#016-160-084; Jackson ImmunoResearch).

Layer-specific stereological analyses in the hippocampus. Within the hippocampal formation, the counting of pyramidal neurons and granule cells was performed in the pyramidal cell layer of the CA1 and CA3 subfields and granule cell layer of the dentate gyrus (DG). The hippocampal subdivisions and layer boundaries were delineated in cresyl violetstained sections (for illustrated technique, see supplemental Fig. 1, available at www.jneurosci.org as supplemental material). A semiautomatic stereology system was used by a trained individual blind to the genotype of each mouse to make unbiased estimates of layer-specific neuronal numbers (i.e., cells with visible nuclei/nucleolus) and volumes on cresyl violet-stained sections. The optical fractionator technique was used to estimate neuronal numbers and the Cavalieri principal to determine hippocampal subfield layer volumes as described by Bonthius et al. (2004).

For both the pyramidal and granule cell layers, the section sampling fraction (ssf) was $1 / 15$, the area sampling fraction (asf) was $0.01 \mu \mathrm{m}$, and the thickness sampling fraction (tsf) was $0.7 \mu \mathrm{m}$. The total number of neurons $(N)$ in each layer brain region was estimated as $N=(\Sigma \mathrm{Q}-)(1 /$ tsf)(1/asf)(1/ssf). The determination of whole hippocampus and layer volumes was performed using point counting (with a $50 \times 50 \mu \mathrm{m}$ superimposed grid) and the Cavalieri principle. Starting at the dorsal surface, both neuron counting and volume-related measurements were performed at the same time in serial order. For all neuronal counting and volumetric analyses, a $10 \times$ objective was used to define the boundaries of the hippocampal subfield layers. Using a $100 \times$ oil-immersion objective, cresyl violet staining was used to localize cell nuclei and then neurons based on cell morphology; only nuclei within clear focus of the dissector probe were counted.

Determination of plaque load. Sixteen- to 19-month-old APP and A7KO-APP mice were processed for histochemistry as described. Whole hippocampus and septum boundaries were outlined, electronically measured, and recorded using StereoInvestigator 8.0 software (MicroBrightField) on five randomly selected serial sections (spaced $140 \mu \mathrm{m}$ apart). Using the Cavalieri principle to determine reference volumes (Bonthius et al., 2004), a $25 \times 25 \mu \mathrm{m}$ grid was superimposed on each section, and the total number of points was recorded for each of these sections that contained the hippocampus and intersected with Congo Red staining. The mean percentage of amyloid plaque load was determined by dividing the total volume of Congo Red staining by the total volume of hippocampus $(\times 100 \%)$.

Soluble and membrane protein extraction. Frozen brain tissue was homogenized and then sonicated in detergent-free radioimmunoprecipitation assay (RIPA)-based buffer plus protease and phosphatase inhibitors, followed by centrifugation at $100,000 \times g$ for $1 \mathrm{~h}$ at $4^{\circ} \mathrm{C}$. The supernatant was removed, and the pellet was sonicated in RIPA buffer containing protease and phosphatase inhibitors, $0.5 \%$ Triton X-100, 0.5\% deoxycholoate, and $0.1 \%$ SDS.

Immunoblot. For detection of oligomers by immunoblot, see Kayed et al. (2007) for more detail. Briefly, frozen hippocampi were homogenized in $100 \mu \mathrm{l}$ of PBS containing protease and phosphatase inhibitors and centrifuged at 10,000 rpm for $5 \mathrm{~min}$ to pellet insoluble material. Supernatant was collected.

For the detection of all other proteins, see Dineley et al. (2001) for more detail. Briefly, frozen tissue was sonicated in a HEPES-based buffer containing protease and phosphatase inhibitors. Protein concentrations were determined with the Pierce Microplate BCA Protein Assay kit (Thermo Fisher Scientific). Samples were mixed with sample buffer, resolved by SDS-PAGE, transferred to polyvinylidene difluoride, and then probed with the appropriate primary and secondary antibodies. Antibodies were visualized using chemiluminescence (ECL), and densitometric analysis was performed using the AlphaEaseFC software (Alpha Innotech) from film exposures in the linear range for each antibody and normalized to control (WT littermate) samples. Normalized control values were determined from each film by averaging control values, dividing each control and transgenic sample density by the average of the control set, and then determining the average and SEM for control and transgenic samples. By loading a fixed, equal amount of protein, several ex-

\section{a Novel Object Recognition}
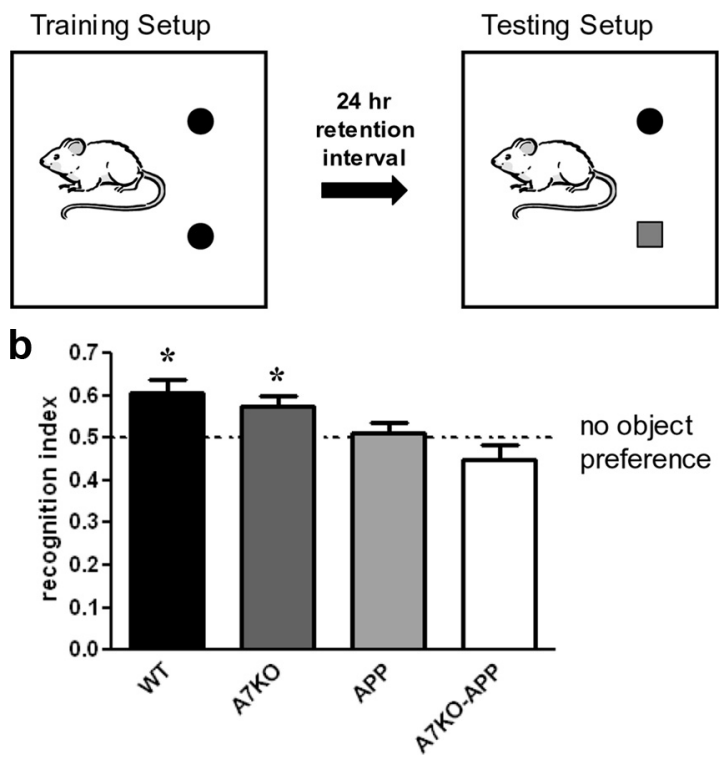

Figure 1. Using a $24 \mathrm{~h}$ retention interval, APP and A7KO-APP exhibit a novel object recognition deficit compared with WT and A7KO. $a$, Schematic for depicting regimen for NOR training and testing. $\boldsymbol{b}$, WT and A7KO mice showed a preference for the novel object after a $24 \mathrm{~h}$ delay between identical object exploration during training and the introduction of a novel object during the test phase. One-sample two-tailed $t$ test against a theoretical mean of 0.5000 yielded $p$ values of 0.003 and 0.018 for WT and A7K0, respectively. APP and A7KO-APP mice did not exhibit any preference for object exploration ( $p=0.671$ and 0.145 , APP and A7K0-APP, respectively). * indicates significant difference from theoretical mean of 0.50 .

periments may be compared with each other. Loading equivalency is verified by probing for an abundant ubiquitous protein such as actin.

ChAT assay. ChAT activity assays were performed according to the Fonnum method (Fonnum, 1975). Briefly, brain tissue was sonicated in homogenization buffer (0.5\% Triton X-100, 10 mm EDTA, pH 7.4, plus protease inhibitors). ChAT activity was measured by incubating samples with $\left[{ }^{14} \mathrm{C}\right]$ acetyl-coenzyme $\mathrm{A}$ in the presence of excess cold substrate and AChE inhibitor for $30 \mathrm{~min}$ at $37^{\circ} \mathrm{C}$. The reaction was stopped with the addition of ice-cold $\mathrm{H}_{2} \mathrm{O} .{ }^{14} \mathrm{C}$-labeled product was separated from the reaction mixture by organic extraction and counted with liquid scintillant for $1 \mathrm{~min}$. Blank samples did not contain any tissue. Olfactory bulb homogenate served as positive control.

ChAT activity was calculated as follows: $\mathrm{CPM}_{\text {sample }}-$ Blank $_{\mathrm{cpm}} \times$ $1 /$ specific activity $\times$ counter efficiency $\times$ volume correction $\times$ time correction $\times 1 / \mu \mathrm{g}$ protein per sample $=\mathrm{nmol} \mathrm{ACh} / \mathrm{h} / \mu \mathrm{g}$ protein.

$A \beta_{1-40}, A \beta_{1-42}$, and APP ELISA. Signal Select (BioSource) was used according to the instructions of the manufacturer. A $\beta$ or APP content was determined by comparison of unknown sample intensity to a standard curve.

Data analysis and statistics. Data were analyzed using GraphPad Prism software.

For novel object recognition tests, the time exploring the novel object (familiar vs novel) is reported as the recognition index and is calculated using the following formula: [(time exploring specified object)/(time exploring novel object + time exploring familiar object) $] \times 100$.

Statistical analysis of NOR data is done by first performing a onesample $t$ test to determine if the mean percentage exploration time is significantly different from a theoretical mean of 0.5000 . This is followed by one-way ANOVA to determine group differences.

Statistical analysis of biochemistry and behavior data was done by one-way ANOVA, followed by Tukey's or Newman-Keuls post hoc tests. For paired analyses, two-way Student's $t$ test was performed. $p \leq 0.05$ is considered significant. Graphs were plotted with mean and SEM. 
aFear Conditioning

2 Pair Training

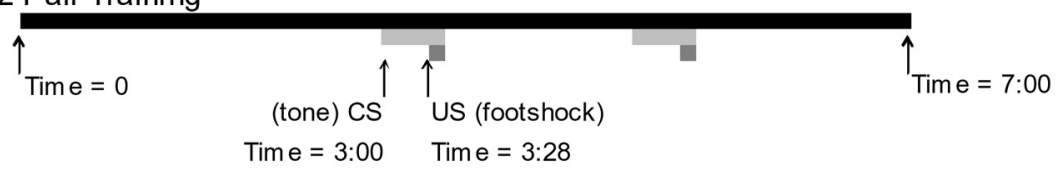

5 Pair Training
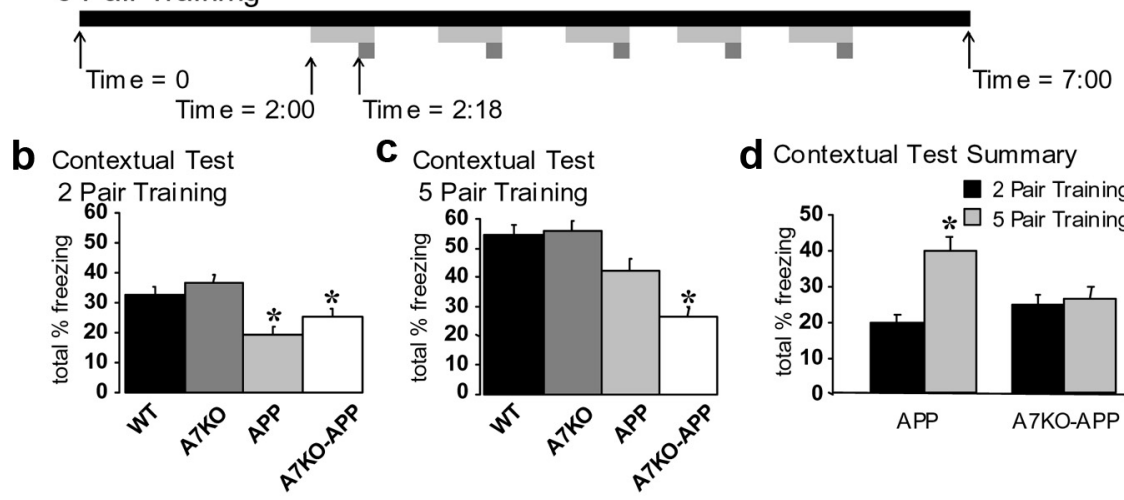

C Contextual Test 5 Pair Training

\section{d Contextual Test Summary}
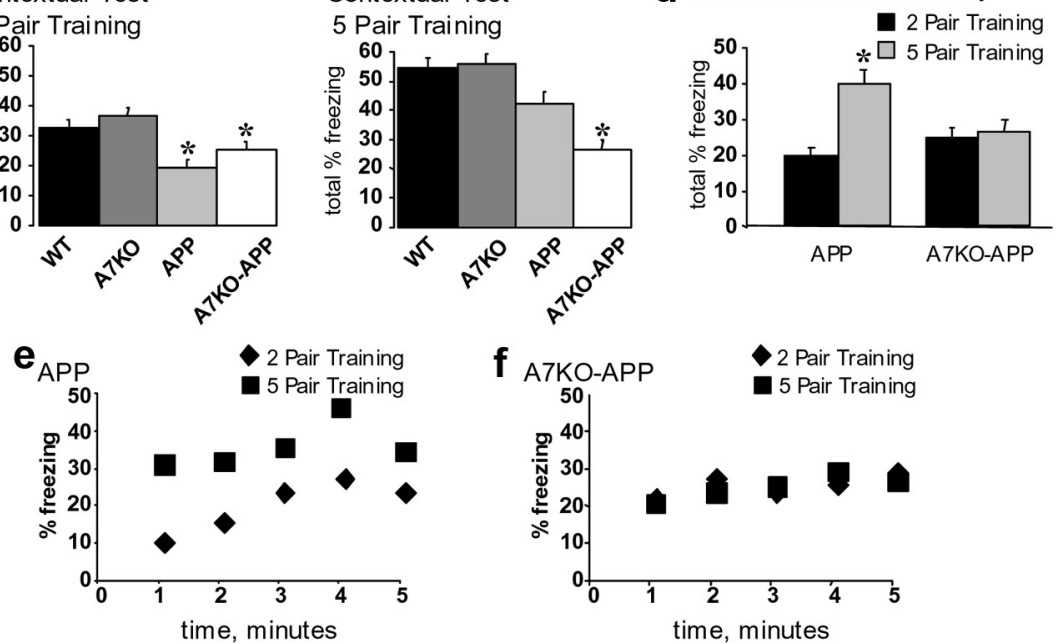

Figure 2. APP performance in the contextual test for fear learning is rescued with five-pair training, but A7K0-APP is not. a, Schematic depicting regimen for training 5-month-old mice for fear conditioning with either two pairs or five pairs of CS-US. Data are expressed as mean \pm SEM total percentage freezing in the contextual test performed $24 \mathrm{~h}$ after two-pair or five-pair training. $\boldsymbol{b}$, APP and A7KO-APP froze less than WT and A7KO after two-pair training. ${ }^{*} p<0.0001$; one-way ANOVA, $F_{(3,225)}=$ 8.82.c, APP fear learning deficit is rescued after five-pair training, but A7KO-APP is not. ${ }^{*} p<0.0001$; one-way ANOVA, $F_{(3,225)}=$ 13.10. $\boldsymbol{d}$, Five-month-old APP performance in contextual fear conditioning significantly improves after five-pair training $\left(p<4 \times 10^{-7}\right.$, Student's $t$ test); A7K0-APP does not ( $\left.p=0.6\right)$. $\boldsymbol{e}, \boldsymbol{f}$, Minute-by-minute plot of mean percentage freezing depicted as total freezing in $\boldsymbol{b}$ and $\boldsymbol{c}$.

\section{Results}

APP cognitive deficits worsen in the absence of $\alpha 7 \mathrm{nAChRs}$ We first determined the behavioral and cognitive effects of deleting the $\alpha 7 \mathrm{nAChR}$ gene product in APP mice. We considered this especially important to pursue because $\alpha 7 \mathrm{nAChRs}$ have been implicated in contradictory roles in the etiology of $\mathrm{AD}$ : activation of $\alpha 7 \mathrm{nAChRs}$ by conventional nicotinic ligands has been shown to be protective against $\mathrm{A} \beta$ toxicity, but $\alpha 7 \mathrm{nAChR}-\mathrm{A} \beta$ interaction has also been suspected in mediating $A \beta$ toxicity (Dineley, 2007; Ren et al., 2007; Clifford et al., 2008; Soderman et al., 2008; Wang et al., 2009). Understanding which phenotype predominates during early-stage cognitive decline will provide great insight into the etiology of AD. Toward this end, A7KO, APP, A7KO-APP, and WT littermates were subjected to general health and behavior assessment, followed by an evaluation of associative learning performance at 5 months of age, the age at which cognitive deficits are first apparent (Dineley et al., 2002b, 2007; Taglialatela et al., 2009). Our standard behavioral screen included, in addition to assessment of such parameters as weight, temperature, general reflexes, etc., evaluation of open-field behavior, rotating rod testing, prepulse inhibition, object recognition, and cued and contextual Pavlovian fear conditioning. This battery of tests allows evaluation of a variety of sensory responses, including hearing and vision, general activity, reflexes, motor coordination, motor learning, and associative learning.
We did not detect statistically significant group differences by genotype regarding weight, temperature, general reflexes, or sensory responses (data not shown). We also did not observe any group differences in the acquisition or performance of the rotating rod test or in prepulse inhibition, indicating that motor learning, coordination, and sensorimotor gating of the startle reflex are normal [supplemental Figs. 2 (rotarod) and 3 (prepulse inhibition), available at www.jneurosci.org as supplemental material]. These results are consistent with previous studies on APP and A7KO mice (Paylor et al., 1998; Dineley et al., 2002b, 2007).

The time spent exploring a novel object versus a familiar object is a measure of attention and nonspatial declarative memory (Broadbent et al., 2004). We have demonstrated previously that 5-month-old APP mice ( $\mathrm{Tg} 2576$ ) are impaired in NOR when the retention interval is manipulated to model intermediate and longterm memory (Taglialatela et al., 2009). The retention interval is the amount of time the animals must retain the memory of the identical three-dimensional objects presented during the training session before the testing session when one of the familiar objects is replaced with a novel one (Fig. 1a). NOR training was performed on 5-month-old WT, A7KO, APP, and A7KO-APP mice. Using a $24 \mathrm{~h}$ retention interval to model long-term memory, WT and A7KO scored recognition indices during the testing phase that were statistically higher than a theoretical mean of 0.5 to represent a "chance" recognition index. However, neither APP nor A7KO-APP mice exhibited any preference for object exploration. One-way ANOVA analysis found that APP and A7KO-APP performance was statistically different from WT littermates $\left(F_{(3,72)}=11.13\right)$ but not each other (Fig. $1 b$ ). Therefore, when a $24 \mathrm{~h}$ retention interval is used to model long-term memory, APP and A7KO-APP mice are impaired in object recognition. Because NOR cannot distinguish degrees of cognitive impairment, our next experiments were designed to address whether A7KO-APP have a more severe cognitive deficit than APP.

Next, 5-month-old WT, A7KO, APP, and A7KO-APP were subjected to two- and five-pair training for fear conditioning (Fig. 2a). As was previously measured in Tg2576 mice, freezing to the context $24 \mathrm{~h}$ after two-pair training for fear conditioning was impaired in the APP mice (Fig. 2b) (Corcoran et al., 2002; Dineley et al., 2002b, 2007; Comery et al., 2005). This deficit was statistically significant compared with both WT and A7KO littermates. Likewise, as was reported previously by Paylor et al. (1998), $\alpha 7$ null mice did not exhibit any deficits in contextual learning. All groups of mice froze to a similar extent in the cued test for fear learning, as reported previously for A7KO and APP mice (supplemental Fig. 4, available at www. jneurosci.org as supplemental material) (Paylor et al., 1998; Dineley et al., 2002b, 2007). In summary, A7KO-APP mice 
exhibited a contextual fear conditioning deficit that was of similar magnitude to the APP littermates. Hence, after twopair training for fear conditioning, APP and A7KO-APP mice are impaired in contextual but not cued memory. Cued conditioning is an index of associative learning that is amygdala dependent and hippocampus independent. Thus, impairment of contextual but not cued fear learning indicates that a selective hippocampus deficit underlies this phenotype.

We have reported previously that the contextual fear learning deficit exhibited by 5 -month-old Tg2576 mice after twopair training is rescued if the animals are put through a more rigorous five-pair training paradigm (Dineley et al., 2002b). This was also the case for the APP mice evaluated in this study. One week after two-pair training, each group of mice was subjected to a five-pair training paradigm. As was the case in our previous study, APP froze in contextual testing to a similar extent as WT littermates (Fig. 2c). As expected, A7KO also froze to the same extent as WT and APP mice (Fig. 2c). In contrast, A7KO-APP mice froze significantly less than all other groups of mice in the contextual test for fear learning (Fig. 2c). All genotypic groups of mice froze to a similar extent in the cued test (data not shown). Statistical analysis of total freezing behavior in the contextual test after two- and five-pair training shows that APP mice significantly improved in the contextual test after five-pair training, whereas A7KO-APP mice did not (Fig. 2d-f).

To verify that the fear conditioning deficit in A7KO-APP mice is an age-dependent and not purely genetic phenomenon, we put 3-month-old A7KO-APP and WT control littermates through the two-pair fear conditioning paradigm, and both groups froze to the same extent in the contextual and cued paradigm (supplemental Fig. 5, available at www.jneurosci. org as supplemental material). Therefore, the deficit detected in these animals at 5 months of age represents an age-dependent decline in hippocampus-dependent cognitive function. Furthermore, loss of $\alpha 7 \mathrm{nAChRs}$ appears to accelerate the cognitive decline in APP mice because, at 5 months of age, APP fear conditioning deficit is rescued with a more rigorous training paradigm and $\mathrm{A} 7 \mathrm{KO}-\mathrm{APP}$ is not.

Hyperactivity or an inability to perceive the shock stimulus might confound our results, especially if hyperactivity results in an inability to freeze; the fact that these animals freeze in the cued test argues against this, but we also evaluated these mice for spontaneous activity in the open-field test. We also measured their threshold to flinch, jump, and vocalize to increasing electrical shock intensities as an index of their sensitivity to the shock stimulus and found no differences. There also were no statistically significant differences by genotype in the distance traveled, rearing, center to distance ratio, or time spent in the center of the open-field box, indicating that the failure of APP and A7KO-APP mice to freeze in the contextual test is not attributable to hyperactivity or hypoanxiety (supplemen- tal Fig. 6, available at www.jneurosci.org as supplemental material).

Total hippocampal $\mathrm{A} \boldsymbol{\beta}$ load is decreased yet $\mathrm{A} \boldsymbol{\beta}_{1-42}$ is enriched in A7KO-APP

Quantification of $A \beta$ in the hippocampus of young and aged APP and $\mathrm{A} 7 \mathrm{KO}-\mathrm{APP}$ mice was measured. Brain tissue was harvested from mice 5 and 12 months of age and then subjected to quantitative $\mathrm{A} \beta$ ELISA specific for human $\mathrm{A} \beta_{1-40}$ and $\mathrm{A} \beta_{1-42}$. Fivemonth-old A7KO-APP mice had an $\sim 50 \%$ reduction in hippocampal $\mathrm{A} \beta_{1-40}$ load compared with APP (Fig. $3 a$ ), but $A \beta_{1-42}$ was not significantly altered. By 12 months of age, both $\mathrm{A} \beta_{1-40}$ and $\mathrm{A} \beta_{1-42}$ levels in A7KO-APP hippocampus were $\sim 70 \%$ lower than that measured in APP (Fig. $3 b$ ). Thus, A7KOAPP mice have a selective reduction in hippocampal A $\beta$ compared with APP. Although significantly lower than APP, the A7KO-APP A $\beta$ load is still abnormally high. At 5 months of age, A7KO-APP hippocampus contains $\sim 60 \mathrm{pmol} / \mathrm{g} \mathrm{A} \beta$; this is approximately sixfold higher than reported for wild-type mice (Kawarabayashi et al., 2001).

Additional analysis of these results by way of calculating the ratio of $\mathrm{A} \beta_{42} / \mathrm{A} \beta_{40}$ demonstrates that, although total $\mathrm{A} \beta$ is lower in A7KO-APP hippocampus, the relative proportion of the more toxic peptide, $\mathrm{A} \beta_{1-42}$, is significantly increased (Fig. 3c). This raises the possibility that the more severely compromised cognitive status of A7KO-APP mice compared with APP may result from selective enrichment for $\mathrm{A} \beta_{1-42}$.

\section{Reduced hippocampal $A \beta$ is accompanied by reduced plaque load in A7KO-APP}

Brain sections from APP and A7KO-APP animals 16-19 months of age were processed for amyloid staining with Congo Red and then assessed for percentage area of the hippocampus occupied by plaques. Consistent with an overall reduction in $\mathrm{A} \beta$ level in A7KO-APP hippocampus, plaque load in these animals was significantly lower than APP. Percentage area values were $0.74 \pm$ 
a APP
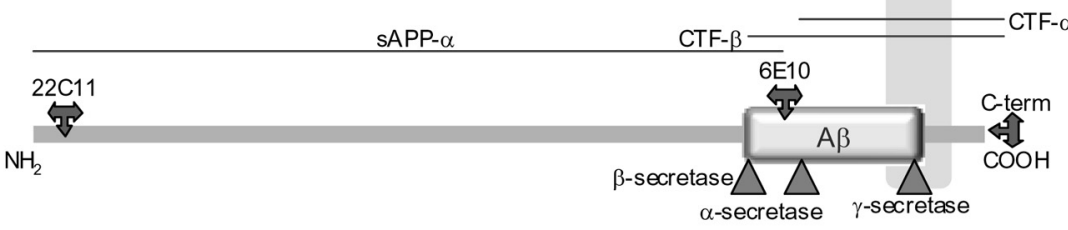

b '6E10'Antibody

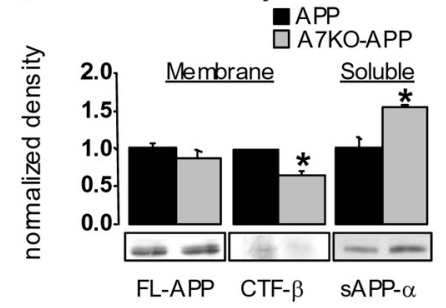

d '22C11' Antibody

Membrane Fraction:

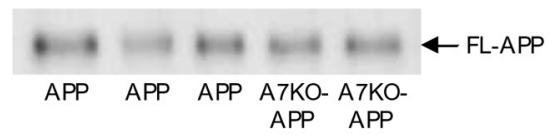

e 'OC' Antibody

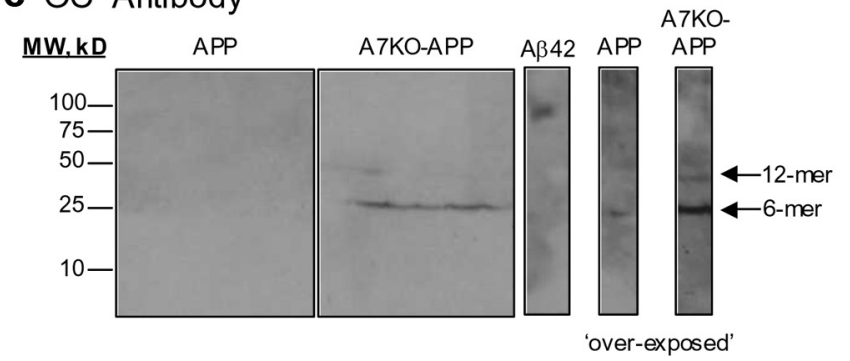

Figure 4. Enhanced accumulation of soluble, fibrillar, oligomeric $A \beta$ and altered APP processing in A7K0-APP hippocampus. $\boldsymbol{a}$, Schematic depicting the APP within the cell membrane. Antibody epitopes and secretase cleavage sites are designated. $\boldsymbol{b}$, Immunoblot with 6 E10 antibody detects full-length APP (FL-APP) transgene and (TF- $\beta$ in hippocampal membrane extracts from 5 -month-old mice. Compared with APP mice, the FL-APP expression is unchanged ( $p>0.05$, Student's $t$ test), but CTF- $\beta$ is decreased in A7KO-APP samples ( $p<0.05$, Student's t test). The soluble product of $\alpha$-secretase cleavage of the APP (SAPP- $\alpha$ ) is enhanced in A7K0-APP hippocampus as detected with 6 E10 immunoblot of soluble protein fraction ( $p<0.05$, Student's $s$ test). Data expressed normalized to APP. c, Using an antibody directed against the C-terminal end of the APP indicates increased CTF- $\alpha$ and decreased CTF- $\beta$ in A7KO-APP hippocampus. Left, Immunoblot; right, quantification of immunoblot results. ${ }^{*} p<0.05$, Student's $t$ test. Data expressed normalized to APP. $\boldsymbol{d}$, Immunoblot with 22C11 antibody illustrates that amyloid precursor protein (holoprotein) expression levels in membrane fractions is unchanged between APP and A7K0-APP. e, Immunoblot with OC antibody demonstrates that A7K0-APP contain two fibrillar, oligomeric amyloid species,. The dodecamer species is absent from APP hippocampus as evidenced by an overexposure of the immunoblot. Positive control $A \beta_{42}$ oligomer preparation is immunopositive for $0 \mathrm{C}$ antibody with molecular weight (MW) of $\sim 120 \mathrm{kDa}$. Image shows APP and A7KO-APP samples with positive $A \beta_{42}$ control cropped from the same immunoblot scan.

0.12 and $0.53 \pm 0.06 \%$ for APP and A7KO-APP, respectively (Fig. 3d).

\section{APP transgene expression was unchanged, and C-terminal fragments indicate altered APP processing in A7KO-APP hippocampus}

Using a combination of antibodies directed against different epitopes of the amyloid precursor protein and probing homogenates fractionated into membrane-associated and soluble material, we evaluated amyloid precursor protein processing in APP and A7KO-APP hippocampus (Fig. 4a). Using 6E10 antibody that recognizes the $\mathrm{N}$-terminal region of human $\mathrm{A} \beta$ to probe membrane preparations indicates that transgene expression is unchanged (Fig. 4b); however, C-terminal fragments (CTFs) generated from $\beta$-secretase cleavage of the holoprotein (CTF- $\beta$ ) are reduced in
A7KO-APP samples compared with APP (Fig. 4b). Soluble hippocampal material probed with $6 \mathrm{E} 10$ antibody indicated that cleavage of the amyloid precursor protein by $\alpha$-secretase (sAPP- $\alpha$ ) is enhanced (Fig. $4 b)$. We verified enhanced $\alpha$-secretase processing of the holoprotein by probing membrane proteins from APP and A7KO-APP hippocampus with an antibody directed against the C-terminal portion of the 695 splice variant of the amyloid precursor protein. Membrane-associated CTFs generated through $\alpha$-secretase cleavage of the APP were increased and those generated through $\beta$-secretase cleavage were reduced in A7KO-APP hippocampus compared with APP (Fig. 4c).

We verified that amyloid precursor protein expression was unchanged by evaluating extracts of hippocampus from 5-month-old APP and A7KO-APP mice. Amyloid precursor protein was detected in membrane preparations by sandwich ELISA that selectively detects the human holoprotein or quantitative immunoblotting using antibody $22 \mathrm{C} 11$ that will detect both mouse and human amyloid precursor protein. With both methods, we found no significant change in amyloid precursor protein level between 5-month-old APP and A7KO-APP in hippocampus (Fig. 4d). Considered together, these results indicate that the amyloid precursor protein in A7KO-APP hippocampus is preferentially processed toward the $\alpha$-secretase pathway and suggests that this mechanism underlies the reduced $A \beta$ load in the hippocampus of these animals. However, it does not account for the shift toward a higher proportion of $\mathrm{A} \beta_{1-42}$ compared with $A \beta_{1-40}$. We next determined whether the shift toward $\mathrm{A} \beta_{1-42}$ in A7KO-APP hippocampus resulted in alterations in oligomeric assemblies of $A \beta$ peptides.

\section{Enhanced $A \boldsymbol{\beta}$ oligomer accumulation in A7KO-APP}

\section{hippocampus}

Many lines of evidence suggest a role for soluble oligomeric $\mathrm{A} \beta$ species in the pathology of AD (Walsh et al., 2002; Lesné et al., 2006; Kayed et al., 2007; Lacor et al., 2007; Venkitaramani et al., 2007; Glabe, 2008; Poling et al., 2008). Previous reports have identified at least two conformationally distinct types of soluble $\mathrm{A} \beta$ oligomers: prefibrillar oligomers and fibrillar oligomers (Kayed et al., 2007; Glabe, 2008). The fibrillar oligomers, as opposed to the prefibrillar oligomers, have been shown recently to correlate with cognitive decline (mini-mental state examination scores) and the neuropathological hallmarks of AD (Tomic et al., 2009).

Soluble oligomeric assemblies of $\mathrm{A} \beta$ were analyzed in hippocampal tissue from $\mathrm{WT}, \mathrm{A} 7 \mathrm{KO}, \mathrm{APP}$, and A7KO-APP animals using immunoblot with $\mathrm{OC}$ antibody, selective for fibrillar 
oligomeric amyloid structures (Kayed et al., 2007; Glabe, 2008). Samples from 5 -month-old animals revealed that A7KO-APP hippocampus exhibits two species of fibrillar oligomeric (OCpositive) assemblies with approximate molecular weights of 27 and $56 \mathrm{kDa}$ (Fig. $4 e$ ). These soluble oligomeric species were essentially absent from WT, A7KO, and APP hippocampus under identical exposure conditions. However, during overexposure, the $27 \mathrm{kDa}$ band, but not $56 \mathrm{kDa}$ band, was present in APP hippocampal samples. Therefore, only 5-month-old A7KO-APP hippocampi contain a soluble, fibrillar, oligomeric $A \beta$ dodecamer at this age. The $56 \mathrm{kDa}$ soluble oligomer does not appear until 6 months of age in Tg2576 brain, suggesting that loss of $\alpha 7 \mathrm{nAChRs}$ influences both APP processing and $\mathrm{A} \beta$ oligomer accumulation in this mouse model (Lesné et al., 2006).

Signs of hippocampal neurodegeneration in A7KO-APP mice The observation that 5-month-old A7KO-APP mice are more severely cognitively impaired than APP littermates, concomitant with enhanced accumulation of soluble $A \beta$ oligomers, prompted us to consider the possibility that this would be accompanied by signs of neurodegeneration. As such, we performed quantitative stereology and biochemical assays to evaluate neuron number, somatodendritic and presynaptic integrity in the hippocampus of 5-month-old WT, A7KO, APP, and A7KO-APP littermates.

We found initial evidence of hippocampal neurodegeneration when we evaluated the levels of the presynaptic marker synaptophysin and the somatodendritic marker MAP2 with quantitative immunoblot. Previous studies on APP mice have failed to detect robust deficits in synaptophysin at any age, and MAP2 decline has only been reported for aged APP animals (9-24 months old) (Savage et al., 2002; Fonseca et al., 2004). These and other studies suggest that postsynaptic structures are more vulnerable than presynaptic ones in APP mice (Spires et al., 2005). Consistent with this, we found no alteration of hippocampal synaptophysin in any of our four genotypic groups of mice ( $p=0.26$, one-way ANOVA, $F_{(3,22)}=1.46$; data not shown). Conversely, MAP2 levels in 5-month-old A7KO and A7KO-APP hippocampus were significantly lower compared with WT and APP littermates, indicating that postsynaptic integrity may be affected by loss of $\alpha 7$ nAChRs (Fig. 5). However, because MAP2 is not specifically localized to dendritic structures, the role of $\alpha 7$ nAChRs in postsynaptic integrity and whether this is accompanied by structural changes in synapses such as dendritic spine loss cannot be addressed with the current methodology.

Next we used quantitative stereological techniques on cresyl violet-stained sections to estimate layer-specific alterations in neuronal number and volume in the hippocampal CA1 and CA3 pyramidal layers and DG granule cell layer of littermate WT, A7KO, APP, and A7KO-APP mice. An example of our cresyl violet staining results compared with NeuN immunoreactivity are shown (Fig. 6), and an illustration of the CA1 and CA3 pyramidal neuron layer boundaries as well as DG granule cell layer boundary used in this study can be found in the supplemental data (supplemental Fig. 1, available at www.jneurosci.org as supplemental material). We discovered alterations in the hip- pocampal formation of both APP and A7KO-APP mice, yet A7KO-APP were more severely affected (Table 1). A7KO-APP hippocampus showed significant reduction in neuron number and volumes in a region- and layer-specific manner. For example, compared with WT, A7KO, and APP littermates, A7KO-APP showed significant decrease in (1) DG granule cell layer volume, (2) CA3 pyramidal neuron number, and (3) CA3 pyramidal neuron layer volume (Table 1 , see ${ }^{\star}$ ). The APP group also exhibited shrinkage of DG granule cell region volume and loss of pyramidal neurons from CA1 (Table 1, see ${ }^{\star}$ ). Loss of CA1 pyramidal neurons without a corresponding loss of CA1 volume suggests that this reduction was not sufficient to influence volume. Because there was not a corresponding loss of granule cells from DG in APP or A7KO-APP hippocampus, this suggests that the volume shrinkage observed is possibly attributable to loss of somatic volume, an idea consistent with the observed reduction in MAP2 with quantitative immunoblot. However, A7KO-APP CA3 pyramidal neuron layer exhibited significant loss of both pyramidal neuron number and layer volume. Future studies will evaluate additional cell populations in hippocampus that are enriched for $\alpha 7$ nAChRs such as interneurons (e.g., GAD67 positive) and glia (e.g., GFAP and $S 100 \beta$ positive) (Khiroug et al., 2003; Teaktong et al., 2003).

Similar volumetric measurements in the septum found no significant volume difference between the four groups of mice $\left(p=0.98\right.$, one-way ANOVA, $F_{(3,20)}=0.07$; data not shown $)$. These results suggest that neuron and volume loss in A7KO-APP occurs first in the hippocampus, a cholinergic target region, rather than in the source nuclei and that the role of $\alpha 7 \mathrm{nAChRs}$ in maintaining hippocampal integrity is evident at a young age (before the onset of plaques). Our next step was to evaluate whether $\alpha 7 \mathrm{nAChRs}$ are also important in the maintenance of septohippocampal cholinergic integrity.

\section{Loss of cholinergic markers and functionality in A7KO-APP mice}

We next evaluated the status of the presynaptically located cholinergic marker ChAT in the hippocampus of 5-month-old WT, A7KO, APP and A7KO-APP mice. Quantitative immunoblot for hippocampal ChAT protein revealed a 50\% reduction in A7KOAPP (Fig. 7a). Reduced ChAT protein in A7KO-APP hippocampus was paralleled by a similar reduction in ChAT enzyme activity (Fig. 7b). The protein signal for VAChT was also assessed in A7KO-APP samples, but this signal did not reach statistical significance ( $p=0.41$, one-way ANOVA, $F_{(3,17)}=1.02$; data not shown). Thus, loss of presynaptic and postsynaptic proteins as 

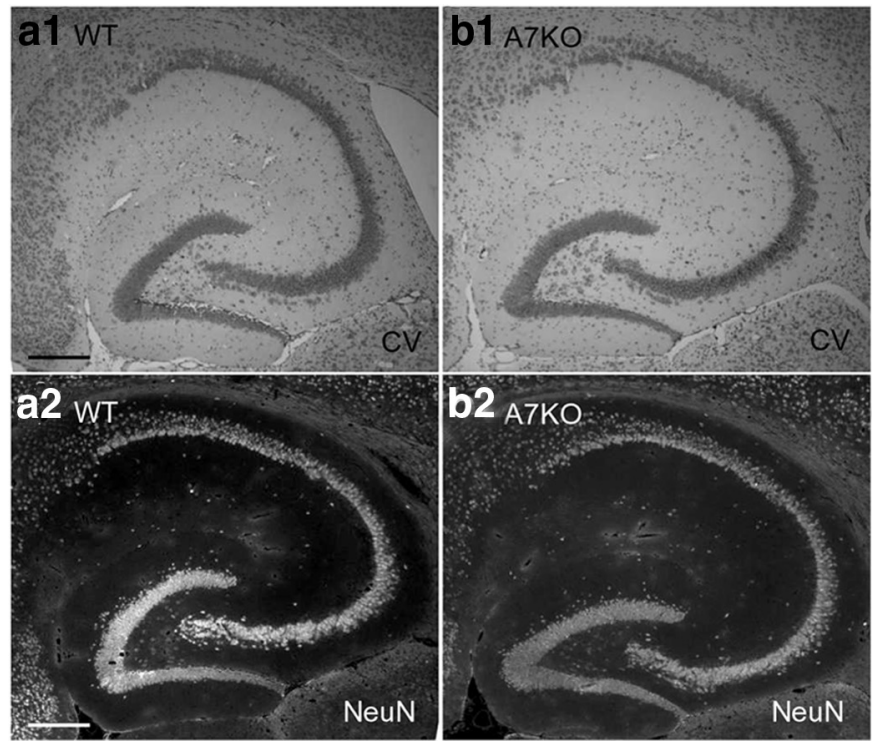
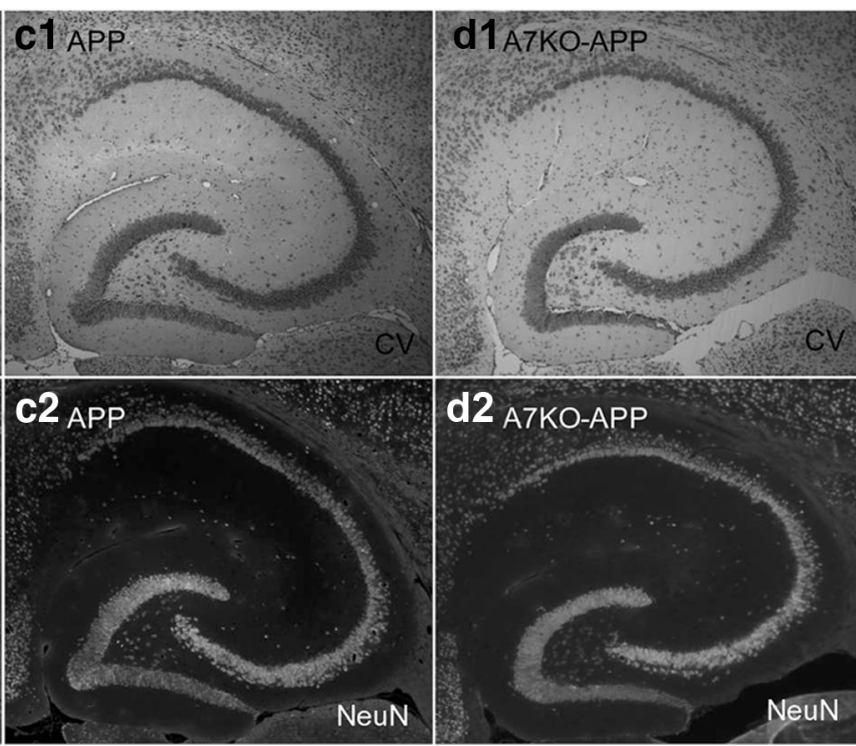

Figure 6. $\quad \boldsymbol{a}-\boldsymbol{d}$, Histological images of the hippocampal formation from young WT (a1, a2), A7K0 (b1, b2), APP (c1, c2), and A7K0-APP (d1, d2) mice. Sections were treated with cresyl violet $(1 ; C V)$ or immunostained with anti-NeuN (2). Images demonstrate that cresyl violet staining can be used to delineate the CA1 pyramidal, CA3 pyramidal, and DG granule cell layers. Scale bar, 500 um.

Table 1. Quantitative stereological analyses of hippocampal neuron counts and volume for WT, A7K0, APP, and A7K0-APP

\begin{tabular}{|c|c|c|c|c|c|c|c|c|}
\hline & \multicolumn{4}{|l|}{ Neuron counts } & \multicolumn{4}{|c|}{ Volume estimate } \\
\hline & WT & A7KO & APP & A7K0-APP & WT & A7KO & APP & A7KO-APP \\
\hline CA1-Pyr & $1.00 \pm 0.04$ & $1.01 \pm 0.11$ & $0.74 \pm 0.12^{*}$ & $1.11 \pm 0.08$ & $1.00 \pm 0.06$ & $0.95 \pm 0.13$ & $0.74 \pm 0.14$ & $0.91 \pm 0.11$ \\
\hline CA3-Pyr & $1.00 \pm 0.09$ & $0.96 \pm 0.05$ & $0.83 \pm 0.06$ & $0.77 \pm 0.03^{*}$ & $1.00 \pm 0.05$ & $0.92 \pm 0.04$ & $0.93 \pm 0.07$ & $0.73 \pm 0.08 *$ \\
\hline DG-Gran & $1.00 \pm 0.07$ & $1.00 \pm 0.07$ & $0.76 \pm 0.11$ & $0.84 \pm 0.08$ & $1.00 \pm 0.05$ & $0.95 \pm 0.05$ & $0.75 \pm 0.06^{*}$ & $0.74 \pm 0.08^{*}$ \\
\hline
\end{tabular}

${ }^{*} p<0.05$ compared with WT. Data expressed normalized to WT. Pyr, Pyramidal layer; Gran, granule cell layer.

well as loss of neurons/volume from hippocampus of A7KOAPP mice reveals more severe neurodegeneration in A7KO-APP hippocampus compared with APP, A7KO, and WT groups. These observations indicate that, in the absence of $\alpha 7 \mathrm{nAChRs}$ and in the presence of excess $\mathrm{A} \beta$, hippocampal cholinergic function and neuron integrity is compromised.

The major source of cholinergic input to the hippocampus and neocortex is from the basal forebrain, including the medial septum, diagonal band nuclei, and basal nucleus. We therefore investigated the relative level of ChAT in this region of WT, A7KO, APP, and A7KO-APP mice. Immunoblot quantification suggested that a trend for decreased ChAT protein in the basal forebrain region of A7KO and A7KO-APP mice was evident (Fig. 7c). When ChAT activity was assayed, we found a statistically significant reduction in enzyme activity in both A7KO and A7KO-APP basal forebrain samples (Fig. $7 d$ ). This suggests that, in vivo and regardless of $\mathrm{A} \beta$ load, $\alpha 7 \mathrm{nAChRs}$ are important for maintaining cholinergic function in the basal forebrain.

We tested whether the loss of hippocampal and basal forebrain ChAT activity in 5-month-old A7KO-APP animals is an agedependent phenomenon by evaluating ChAT activity in 3-monthold WT, A7KO, APP, and A7KO-APP mice. At this age, all genotypic groups exhibited statistically equivalent ChAT activity in hippocampus and basal forebrain (supplemental Fig. 7, available at www.jneurosci.org as supplemental material), but ChAT activity in genotypes lacking the $\alpha 7 \mathrm{nAChR}$ showed a definite trend for upregulation. This observation is similar to those made in human postmortem brain in which ChAT activity is upregulated in samples from patients with early AD (DeKosky et al., 2002; Ikonomovic et al.,
2003; Counts et al., 2007). This suggests that the loss of ChAT protein and activity is both age and $\alpha 7 \mathrm{nAChR}$ dependent.

\section{Loss of ERK activity in A7KO-APP hippocampus}

In addition to its well known role in neuroprotection, the ERK mitogen-activated protein kinase (MAPK) cascade is important for certain hippocampus-dependent learning and memory tasks, including contextual fear conditioning (Atkins et al., 1998). We have shown previously that soluble oligomeric $A \beta$, composed mainly of trimers and hexamers, activates ERK MAPK via $\alpha 7$ nAChRs (Dineley et al., 2001; Bell et al., 2004). Given the enhancement of hexameric (and higher) A $\beta$ assemblies in the A7KO-APP brain, we wanted to assess the status of ERK protein and its activation state in A7KO-APP hippocampus. Using quantitative immunoblot technique, we probed for total ERK MAPK as well as the phosphorylated, and therefore activated, form of ERK MAPK (phospho-ERK). Although total ERK MAPK was unaltered, we found a significant reduction in phospho-ERK in the A7KO-APP samples (Fig. 8). There were no alterations in the other groups of mice. The fact that A7KO hippocampal ERK MAPK activity was unaffected suggests that under normal $A \beta$ conditions, baseline ERK MAPK activity is not primarily dependent on functional $\alpha 7$ nAChRs. APP ERK MAPK was also unaffected; we have reported previously that hippocampal ERK MAPK activity is elevated in dentate gyrus, but not CA1, in similarly aged APP (Dineley et al., 2001). The fact that we analyzed the entire hippocampus in this experiment may have masked regional differences detected previously. Nonetheless, these observations show that a known downstream target of hippocampal 
$\alpha 7 \mathrm{nAChR}$ activation, ERK MAPK, is negatively affected when this receptor is absent.

\section{Discussion}

$\alpha 7$ nAChRs maintain hippocampal integrity and the septohippocampal cholinergic phenotype

Experimental destruction of septohippocampal cholinergic neurons universally results in reduced cholinergic markers in hippocampus. Most notably, this is expressed as reduced ChAT activity within hippocampus (Kuo et al., 1996; Tapiola et al., 2000; Andreasen et al., 2003). Consistent with lesion studies and observations in $\mathrm{AD}$ brain, compromise of basal forebrain cholinergic function leads to similar concessions within the hippocampus of 5-month-old A7KO-APP mice, supporting the notion that compromise of basal forebrain cholinergic neurons is the underlying mechanism for ChAT reduction in A7KO-APP hippocampus. However, the fact that $\mathrm{A} 7 \mathrm{KO}$ mice exhibit loss of ChAT activity in basal forebrain with no effect on hippocampal ChAT indicates that the added stress of excess $A \beta$ in conjunction with loss of $\alpha 7 \mathrm{nAChRs}$ is necessary to induce such changes in 5-month-old animals.

Previous work on an APP mouse model found impaired cholinergic neurotransmission in the cortex and hippocampus but not the basal forebrain of 19- to 21-month-old animals (Apelt et al., 2002; Lüth et al., 2003). Thus, the A7KO-APP mouse model for AD is the first to exhibit significant cholinergic hypofunction within the basal forebrain and a critical cholinergic projection area: the hippocampus.

\section{Accelerated cognitive decline in}

A7KO-APP mice

We found that hippocampus-dependent memory deficits detected previously in APP mice are more severe when $\alpha 7$ nAChRs are absent. A7KO mice are cognitively normal; thus cognitive deficits in A7KO-APP cannot be directly attributed to loss of $\alpha 7$ nAChRs (Paylor et al., 1998). In contrast, hippocampal ACh neurotransmission is an essential component during the acquisition and retrieval phases of context-dependent learning such as fear conditioning and NOR (Scali et al., 1997; Nail-Boucherie et al., 2000; Sanders et al., 2003; Rogers and Kesner, 2004; Winters et al., 2008). Therefore, the combined loss of cholinergic activity and hippocampal integrity likely contributes to the accelerated de-
Hippocampus

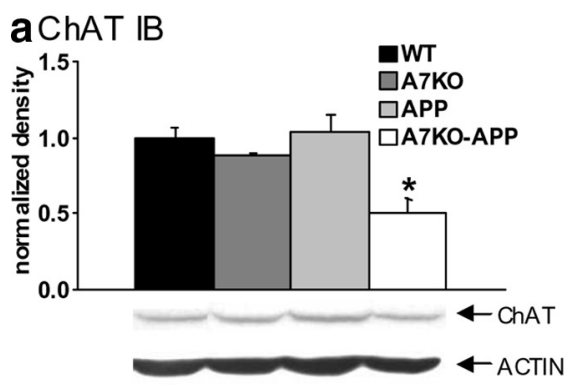

b ChAT activity

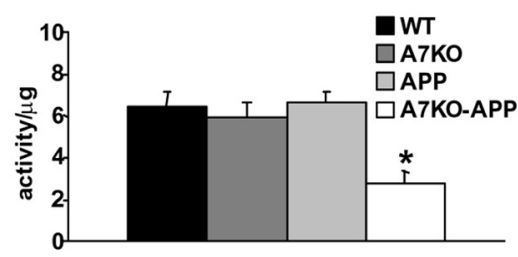
c ChAT IB
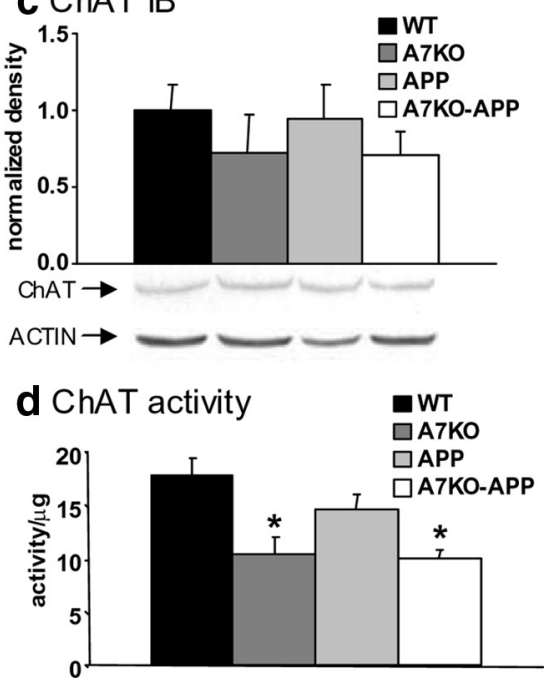

Basal Forebrain

Figure 7. Five-month-old A7K0-APP mice have reduced ChAT protein and activity in hippocampus $(\boldsymbol{a}, \boldsymbol{b})$ and basal forebrain $(\boldsymbol{c}, \boldsymbol{d})$. a, Quantification of band intensity after immunoblot reveals a $50 \%$ reduction in ChAT protein in the hippocampus of A7K0-APP mice. ${ }^{*} p<0.02$, one-way ANOVA, $F_{(3,20)}=8.02$. $\boldsymbol{b}$, ChAT activity in hippocampus of A7K0-APP mice is also reduced. ${ }^{*} p<0.03$, one-way ANOVA, $F_{(3,31)}=3.61$. c, Quantification of band intensity after immunoblot for ChAT did not reveal statistically significant differences in ChAT protein in the basal forebrain. $p=0.3$, one-way ANOVA, $F_{(3,20)}=1.12$.d, ChAT activity in basal forebrain is reduced in A7K0 and A7K0-APP mice. ${ }^{*} p<0.01$, one-way ANOVA, $F_{(3,19)}=5.93$. ChAT immunoblot (IB) data (mean \pm SEM) are expressed normalized to WT samples. ChAT activity data are expressed as mean activity per microgram of protein \pm SEM.

\section{a Phospho-ERK2}

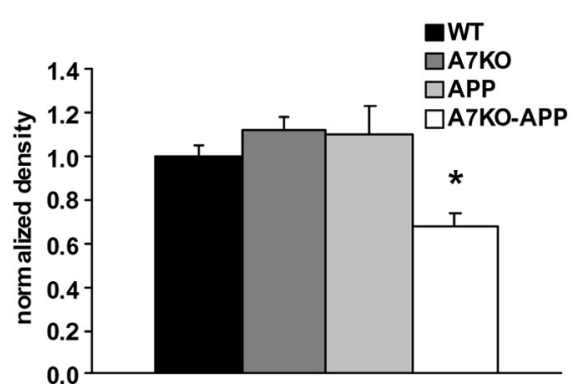

\section{b Total ERK2}

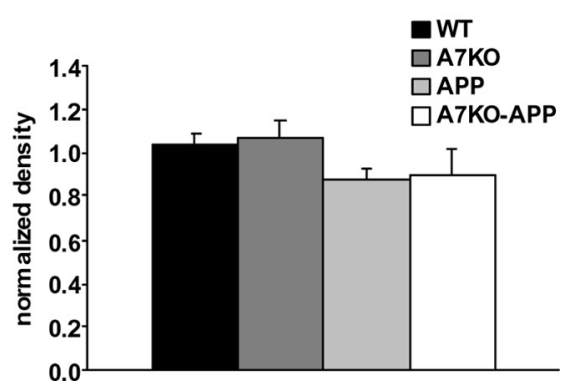

Figure 8. Five-month-old A7KO-APP mice have reduced hippocampal ERK activity with no alteration in total ERK. a, Quantification of band intensity after immunoblot for phospho-ERK reveals significant reduction in ERK activity in A7K0-APP hippocampus. ${ }^{*} p=0.016$ (significant difference from WT, A7KO, and APP), one-way ANOVA, followed by Tukey's post hoc analyses, $F_{(3,117)}=3.57$. $\boldsymbol{b}$, Total ERK reveals no significant differences in hippocampal total ERK protein between the four genotypes. $p=0.3$, one-way ANOVA, $F_{(3,117)}=1.19$. Data expressed as mean \pm SEM, normalized to WT.

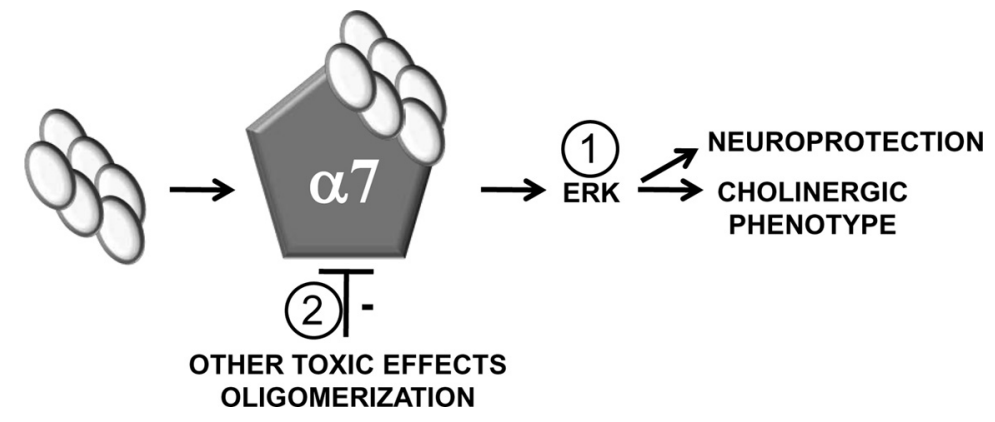

Figure 9. A two-pronged model for $\alpha 7 \mathrm{nAChR}$ neuroprotection in early AD. 1, Low concentrations of A $\beta$ oligomer assemblies can activate $\alpha 7 \mathrm{nAChRs}$, leading to ERK MAPK activation that couples to neuroprotective signaling and maintenance of the cholinergic phenotype. 2, The high-affinity interaction between $\mathrm{A} \beta$ and the $\alpha 7 \mathrm{nAChR}$ leads to prolonged association, thereby retarding additional $A \beta$ oligomerization as well as preventing toxic interactions with other hippocampal targets. 
cline of cognitive function in 5-month-old A7KO-APP mice compared with their APP littermates.

Similar to the human disease, the underlying mechanisms for cognitive impairment in older APP animals are likely distinct from those underlying cognitive deficits in 5-month-old animals. In fact, $\alpha 7 \mathrm{nAChRs}$ may perform a deleterious role in later-stage $\mathrm{AD}$ as exemplified by 13- to 22-month-old PDAPP in which $\alpha 7$ $\mathrm{nAChR}$ deletion improved cognitive performance (Dziewczapolski et al., 2009). Such an antithetical outcome may reflect a dynamic relationship between $\alpha 7 \mathrm{nAChRs}$ and age-dependent $\mathrm{A} \beta$ accumulation and aggregation, discussed below.

\section{Reduced total $A \beta$, enriched $A \beta_{42}$, and enhanced $A \beta$ oligomers in A7KO-APP hippocampus}

Although hippocampal A $\beta$ load was significantly reduced compared with APP mice, the amount of $\mathrm{A} \beta$ in the hippocampus of A7KO-APP mice is still abnormally high when compared with wild-type values (Kawarabayashi et al., 2001). Reductions in A $\beta$ load in A7KO-APP hippocampus were not attributable to altered expression of the human $\mathrm{APP}^{\mathrm{SWE}}$ transgene, suggesting that reduction in A7KO-APP A $\beta$ load is likely the result of enhanced $\alpha$-secretase processing of the APP holoprotein. This latter fact was demonstrated with immunoblot analyses of membraneassociated and soluble APP metabolites; reductions in hippocampal CTF- $\beta$ were concomitant with elevations of CTF- $\alpha$ and sAPP- $\alpha$.

Although total $\mathrm{A} \beta$ is reduced in $\mathrm{A} 7 \mathrm{KO}-\mathrm{APP}$ hippocampus, the $A \beta$ species considered to be more prone to aggregation, and therefore more toxic, $A \beta_{1-42}$ is enriched along with the enhanced accumulation of soluble fibrillar oligomers. Soluble, fibrillar, oligomeric $\mathrm{A} \beta$ has recently been implicated in correlating most strongly with cognitive status in mild cognitive impairment and early AD (Tomic et al., 2009). These observations on A $\beta$ species and assemblies in A7KO-APP hippocampus may be related to effects on hippocampal $\mathrm{A} \beta$ accumulation in the absence of $\alpha 7$ $\mathrm{nAChRs}$. In addition, $\alpha 7 \mathrm{nAChR}$ influence on APP processing and $A \beta$ accumulation may also depend on the APP sequence itself because $\mathrm{A} \beta$ accumulation in the PDAPP mouse model expressing a different APP mutant (containing both the "Swedish" and "Indiana" mutations) did not exhibit any differences in APP processing or A $\beta$ levels (Dziewczapolski et al., 2009). Nonetheless, greater understanding of the relationship between $\alpha 7$ nAChRs, APP processing, and $\mathrm{A} \beta$ accumulation in the hippocampus may allow positive modulation of these processes and lead to useful therapeutic strategies in early AD.

\section{$\alpha 7 \mathrm{nAChRs}$ are neuroprotective in early AD}

Several studies have demonstrated that $\mathrm{nAChR}$ activation attenuates $\mathrm{A} \beta$ toxicity and promotes the integrity of the cholinergic phenotype; protection from $\mathrm{A} \beta$ toxicity is proportional to the number of $\alpha 7$ nAChRs expressed by cells (Kihara et al., 1997; Jonnala and Buccafusco, 2001). APP mice continue to upregulate $\alpha 7 \mathrm{nAChRs}$ as $\mathrm{A} \beta$ accumulates, which is possibly why this $\mathrm{AD}$ model does not exhibit significant loss of cholinergic function and neurodegeneration (Dineley et al., 2001, 2002b). We have shown previously that picomolar to nanomolar $\mathrm{A} \beta_{42}$ oligomer preparations activate $\alpha 7 \mathrm{nAChRs}$, leading to $\mathrm{Ca}^{2+}$ influx and ERK MAPK activation, a second-messenger system not only important for learning and memory but also important for resistance to A $\beta$ toxicity (Dineley et al., 2001, 2002a; Bell et al., 2004). Thus, the observed loss of basal ERK activity in A7KO-APP hippocampus may contribute to one or all of the following observations in these mice: learning and memory deficits, loss of cholinergic functionality, and hippocampal neurodegeneration (Sweatt, 2001; Thatcher et al., 2006; Williams et al., 2007).

We propose a model for early $\mathrm{AD}$ in which $\alpha 7 \mathrm{nAChRs}$ are neuroprotective through a two-pronged mechanism (Fig. 9). The first prong of our model proposes that oligomeric $A \beta$ is capable of transiently activating $\alpha 7 \mathrm{nAChRs}$ with subsequent activation of its downstream messengers that provide a crucial neurotrophic signal for the maintenance of septohippocampal integrity (Williams et al., 2007). The second prong of our model posits that $\alpha 7 \mathrm{nAChRs}$ also counterbalance the toxic effects of $\mathrm{A} \beta$ oligomer accumulation. This is based on our observation that hexameric and dodecameric $\mathrm{A} \beta$ assemblies are enhanced in A7KO-APP hippocampus. $\mathrm{A} \beta-\alpha 7 \mathrm{nAChR}$ interaction may sequester $\mathrm{A} \beta$ during early $\mathrm{AD}$ as well as retard the progression of oligomerization. Thus, in early $\mathrm{AD}, \alpha 7 \mathrm{nAChRs}$ serve a neuroprotective role through both receptor activation and harboring oligomeric $\mathrm{A} \beta$ away from additional toxic interactions (Walsh et al., 2002, 2005).

As $\mathrm{AD}$ progresses and $\mathrm{A} \beta$ oligomers accumulate, we envision that $\mathrm{A} \beta-\alpha 7 \mathrm{nAChR}$ interaction eventually leads to functional blockade of $\alpha 7 \mathrm{nAChRs}$ through essentially irreversible association with $\mathrm{A} \beta$. In fact, $\alpha 7 \mathrm{nAChR}$-selective agonists are unable to activate these receptors in APP transgenic mice, and recent work on human $\mathrm{AD}$ postmortem tissue indicates that much of the receptor protein is functionally inactivated as a result of association with A $\beta$ peptide (Perry et al., 1978; Banerjee et al., 2000; Martin-Ruiz et al., 2000; Dineley et al., 2001 2002b; Teaktong et al., 2003; Counts et al., 2007; Ren et al., 2007; Soderman et al., 2008; Ikonomovic et al., 2009; Wang et al., 2009; Yu et al., 2009). In contrast to its role in early $\mathrm{AD}, \alpha 7 \mathrm{nAChRs}$ may actually contribute to the pathology of late-stage $\mathrm{AD}$ through deleterious effects on synaptic integrity, cholinergic functionality, and cognition. In support of this notion is a recent study in which deletion of $\alpha 7 \mathrm{nAChRs}$ from the PDAPP mouse model led to an improvement in cognition in aged (13-22 months) animals (Dziewczapolski et al., 2009).

In summary, this study has shown that, at an age when APP mice first exhibit cognitive deficits, A7KO-APP mice exhibit more pronounced $\mathrm{AD}$-like pathology: enhanced accumulation of soluble oligomeric $\mathrm{A} \beta$, more severe cognitive impairment, loss of hippocampal markers, loss of cholinergic functionality, and loss of hippocampal neuron number and volume. The results presented here suggest that the hippocampus is particularly vulnerable to the absence of $\alpha 7 \mathrm{nAChRs}$ during early-stage cognitive decline induced by elevated $\mathrm{A} \beta$ and other APP metabolites.

Future work on this animal model will strive to reconcile the following: (1) the influence of neuronal versus glial cell populations on the A7KO-APP phenotype because $\alpha 7 \mathrm{nAChRs}$ are expressed by both of these cell types (Teaktong et al., 2003); (2) how loss of $\alpha 7 \mathrm{nAChRs}$ on interneurons contributes to hippocampal dysfunction in A7KO-APP mice because $\alpha 7 \mathrm{nAChRs}$ are particularly enriched on this hippocampal neuron population (Khiroug et al., 2003); and (3) whether presynaptic versus somatodendritic $\alpha 7 \mathrm{nAChRs}$ differentially contribute to neuroprotection or neurotoxicity because there is evidence that $\mathrm{A} \beta$ activates presynaptic $\alpha 7 \mathrm{nAChRs,} \mathrm{whereas} \mathrm{much} \mathrm{evidence} \mathrm{sug-}$ gests that $\mathrm{A} \beta$ blocks somatodendritic $\alpha 7 \mathrm{nAChRs}$ (Liu et al., 2001; Pettit et al., 2001; Dougherty et al., 2003). Perhaps the neuroprotective role for $\alpha 7 \mathrm{nAChRs}$ resides primarily within the somatodendritic receptors, whereas the toxicity of $\mathrm{A} \beta$ may be primarily through activation of those residing on presynaptic boutons. These last investigations must be accompanied by higher-resolution quantitative assessments of synaptic integrity, 
e.g., spine density, to further the initial evaluation of hippocampal structural integrity performed herein.

\section{References}

Andreasen N, Vanmechelen E, Vanderstichele H, Davidsson P, Blennow K (2003) Cerebrospinal fluid levels of total-tau, phospho-tau and A beta 42 predicts development of Alzheimer's disease in patients with mild cognitive impairment. Acta Neurol Scand Suppl 179:47-51.

Apelt J, Kumar A, Schliebs R (2002) Impairment of cholinergic neurotransmission in adult and aged transgenic Tg2576 mouse brain expressing the Swedish mutation of human beta-amyloid precursor protein. Brain Res 953:17-30.

Atkins CM, Selcher JC, Petraitis JJ, Trzaskos JM, Sweatt JD (1998) The MAPK cascade is required for mammalian associative learning. Nat Neurosci 1:602-609.

Azam L, Winzer-Serhan U, Leslie FM (2003) Co-expression of alpha7 and beta2 nicotinic acetylcholine receptor subunit mRNAs within rat brain cholinergic neurons. Neuroscience 119:965-977.

Banerjee C, Nyengaard JR, Wevers A, de Vos RA, Jansen Steur EN, Lindstrom J, Pilz K, Nowacki S, Bloch W, Schröder H (2000) Cellular expression of alpha7 nicotinic acetylcholine receptor protein in the temporal cortex in Alzheimer's and Parkinson's disease: a stereological approach. Neurobiol Dis 7:666-672.

Bell KA, O’Riordan KJ, Sweatt JD, Dineley KT (2004) MAPK recruitment by beta-amyloid in organotypic hippocampal slice cultures depends on physical state and exposure time. J Neurochem 91:349-361.

Bonthius DJ, McKim R, Koele L, Harb H, Karacay B, Mahoney J, Pantazis NJ (2004) Use of frozen sections to determine neuronal number in the murine hippocampus and neocortex using the optical dissector and optical fractionator. Brain Res Brain Res Protoc 14:45-57.

Broadbent NJ, Squire LR, Clark RE (2004) Spatial memory, recognition memory, and the hippocampus. Proc Natl Acad Sci US A 101:14515-14520.

Clifford PM, Siu G, Kosciuk M, Levin EC, Venkataraman V, D’Andrea MR, Nagele RG (2008) Alpha7 nicotinic acetylcholine receptor expression by vascular smooth muscle cells facilitates the deposition of Abeta peptides and promotes cerebrovascular amyloid angiopathy. Brain Res 1234:158-171.

Comery TA, Martone RL, Aschmies S, Atchison KP, Diamantidis G, Gong X, Zhou H, Kreft AF, Pangalos MN, Sonnenberg-Reines J, Jacobsen JS, Marquis KL (2005) Acute gamma-secretase inhibition improves contextual fear conditioning in the Tg2576 mouse model of Alzheimer's disease. J Neurosci 25:8898-8902.

Corcoran KA, Lu Y, Turner RS, Maren S (2002) Overexpression of hAPPswe impairs rewarded alternation and contextual fear conditioning in a transgenic mouse model of Alzheimer's disease. Learn Mem 9:243-252.

Counts SE, He B, Che S, Ikonomovic MD, DeKosky ST, Ginsberg SD, Mufson EJ (2007) Alpha7 nicotinic receptor up-regulation in cholinergic basal forebrain neurons in Alzheimer disease. Arch Neurol 64:1771-1776.

de Bruin N, Pouzet B (2006) Beneficial effects of galantamine on performance in the object recognition task in Swiss mice: deficits induced by scopolamine and by prolonging the retention interval. Pharmacol Biochem Behav 85:253-260.

DeKosky ST, Ikonomovic MD, Styren SD, Beckett L, Wisniewski S, Bennett DA, Cochran EJ, Kordower JH, Mufson EJ (2002) Upregulation of choline acetyltransferase activity in hippocampus and frontal cortex of elderly subjects with mild cognitive impairment. Ann Neurol 51:145-155.

Dineley KT (2007) Beta-amyloid peptide: nicotinic acetylcholine receptor interaction: the two faces of health and disease. Front Biosci 12:5030-5038.

Dineley KT, Westerman M, Bui D, Bell K, Ashe KH, Sweatt JD (2001) $\beta$-Amyloid activates the mitogen-activated protein kinase cascade via hippocampal $\alpha 7$ nicotinic acetylcholine receptors: in vitro and in vivo mechanisms related to Alzheimer's disease. J Neurosci 21:4125-4133.

Dineley KT, Bell KA, Bui D, Sweatt JD (2002a) beta-Amyloid peptide activates alpha 7 nicotinic acetylcholine receptors expressed in Xenopus oocytes. J Biol Chem 277:25056-25061.

Dineley KT, Xia X, Bui D, Sweatt JD, Zheng H (2002b) Accelerated plaque accumulation, associative learning deficits and up-regulation of alpha 7 nicotinic receptor protein in transgenic mice co-expressing mutant human presenilin 1 and amyloid precursor proteins. J Biol Chem 277:22768-22780.
Dineley KT, Hogan D, Zhang WR, Taglialatela G (2007) Acute inhibition of calcineurin restores associative learning and memory in Tg2576 APP transgenic mice. Neurobiol Learn Mem 88:217-224.

Dougherty JJ, Wu J, Nichols RA (2003) $\beta$-Amyloid regulation of presynaptic nicotinic receptors in rat hippocampus and neocortex. J Neurosci 23:6740-6747.

Dziewczapolski G, Glogowski CM, Masliah E, Heinemann SF (2009) Deletion of the $\alpha 7$ nicotinic acetylcholine receptor gene improves cognitive deficits and synaptic pathology in a mouse model of Alzheimer's disease. J Neurosci 29:8805-8815.

Fabian-Fine R, Skehel P, Errington ML, Davies HA, Sher E, Stewart MG, Fine A (2001) Ultrastructural distribution of the $\alpha 7$ nicotinic acetylcholine receptor subunit in rat hippocampus. J Neurosci 21:7993-8003.

Fonnum F (1975) A rapid radiochemical method for the determination of choline acetyltransferase. J Neurochem 24:407-409.

Fonseca MI, Zhou J, Botto M, Tenner AJ (2004) Absence of C1q leads to less neuropathology in transgenic mouse models of Alzheimer's disease. J Neurosci 24:6457-6465.

Glabe CG (2008) Structural classification of toxic amyloid oligomers. J Biol Chem 283:29639-29643.

Hsiao K, Chapman P, Nilsen S, Eckman C, Harigaya Y, Younkin S, Yang F, Cole G (1996) Correlative memory deficits, Abeta elevation, and amyloid plaques in transgenic mice. Science 274:99-102.

Hunt SP, Schmidt J (1978) The electron microscopic autoradiographic localization of alpha-bungarotoxin binding sites within the central nervous system of the rat. Brain Res 142:152-159.

Ikonomovic MD, Mufson EJ, Wuu J, Cochran EJ, Bennett DA, DeKosky ST (2003) Cholinergic plasticity in hippocampus of individuals with mild cognitive impairment: correlation with Alzheimer's neuropathology. J Alzheimers Dis 5:39-48.

Ikonomovic MD, Wecker L, Abrahamson EE, Wuu J, Counts SE, Ginsberg SD, Mufson EJ, Dekosky ST (2009) Cortical alpha7 nicotinic acetylcholine receptor and beta-amyloid levels in early Alzheimer disease. Arch Neurol 66:646-651.

Jacobsen JS, Wu CC, Redwine JM, Comery TA, Arias R, Bowlby M, Martone R, Morrison JH, Pangalos MN, Reinhart PH, Bloom FE (2006) Earlyonset behavioral and synaptic deficits in a mouse model of Alzheimer's disease. Proc Natl Acad Sci U S A 103:5161-5166.

Jonnala RR, Buccafusco JJ (2001) Relationship between the increased cell surface alpha7 nicotinic receptor expression and neuroprotection induced by several nicotinic receptor agonists. J Neurosci Res 66:565-572.

Kawarabayashi T, Younkin LH, Saido TC, Shoji M, Ashe KH, Younkin SG (2001) Age-dependent changes in brain, CSF, and plasma amyloid $\beta$ protein in the Tg2576 transgenic mouse model of Alzheimer's disease. J Neurosci 21:372-381.

Kayed R, Head E, Sarsoza F, Saing T, Cotman CW, Necula M, Margol L, Wu J, Breydo L, Thompson JL, Rasool S, Gurlo T, Butler P, Glabe CG (2007) Fibril specific, conformation dependent antibodies recognize a generic epitope common to amyloid fibrils and fibrillar oligomers that is absent in prefibrillar oligomers. Mol Neurodegener 2:18.

Khiroug L, Giniatullin R, Klein RC, Fayuk D, Yakel JL (2003) Functional mapping and $\mathrm{Ca}^{2+}$ regulation of nicotinic acetylcholine receptor channels in rat hippocampal CA1 neurons. J Neurosci 23:9024-9031.

Kihara T, Shimohama S, Sawada H, Kimura J, Kume T, Kochiyama H, Maeda T, Akaike A (1997) Nicotinic receptor stimulation protects neurons against beta-amyloid toxicity. Ann Neurol 42:159-163.

Kihara T, Shimohama S, Sawada H, Honda K, Nakamizo T, Shibasaki H, Kume T, Akaike A (2001) alpha 7 nicotinic receptor transduces signals to phosphatidylinositol 3-kinase to block A beta-amyloid-induced neurotoxicity. J Biol Chem 276:13541-13546.

Kihara T, Sawada H, Nakamizo T, Kanki R, Yamashita H, Maelicke A, Shimohama S (2004) Galantamine modulates nicotinic receptor and blocks Abeta-enhanced glutamate toxicity. Biochem Biophys Res Commun 325:976-982.

Kuo YM, Emmerling MR, Vigo-Pelfrey C, Kasunic TC, Kirkpatrick JB, Murdoch GH, Ball MJ, Roher AE (1996) Water-soluble Abeta (N-40, $\mathrm{N}-42$ ) oligomers in normal and Alzheimer disease brains. J Biol Chem 271:4077-4081.

Lacor PN, Buniel MC, Furlow PW, Clemente AS, Velasco PT, Wood M, Viola KL, Klein WL (2007) Abeta oligomer-induced aberrations in synapse composition, shape, and density provide a molecular basis for loss of connectivity in Alzheimer's disease. J Neurosci 27:796-807. 
Lesné S, Koh MT, Kotilinek L, Kayed R, Glabe CG, Yang A, Gallagher M, Ashe KH (2006) A specific amyloid-beta protein assembly in the brain impairs memory. Nature 440:352-357.

Liu Q, Kawai H, Berg DK (2001) beta -Amyloid peptide blocks the response of alpha 7-containing nicotinic receptors on hippocampal neurons. Proc Natl Acad Sci U S A 98:4734-4739.

Li XD, Arias E, Jonnala RR, Mruthinti S, Buccafusco JJ (2005) Effect of amyloid peptides on the increase in TrkA receptor expression induced by nicotine in vitro and in vivo. J Mol Neurosci 27:325-336.

Lüth HJ, Apelt J, Ihunwo AO, Arendt T, Schliebs R (2003) Degeneration of beta-amyloid-associated cholinergic structures in transgenic APP SW mice. Brain Res 977:16-22.

Martin-Ruiz C, Court J, Lee M, Piggott M, Johnson M, Ballard C, Kalaria R, Perry R, Perry E (2000) Nicotinic receptors in dementia of Alzheimer, Lewy body and vascular types. Acta Neurol Scand Suppl 176:34-41.

Nail-Boucherie K, Dourmap N, Jaffard R, Costentin J (2000) Contextual fear conditioning is associated with an increase of acetylcholine release in the hippocampus of rat. Brain Res Cogn Brain Res 9:193-197.

Orr-Urtreger A, Seldin MF, Baldini A, Beaudet AL (1995) Cloning and mapping of the mouse alpha 7-neuronal nicotinic acetylcholine receptor. Genomics 26:399-402.

Orr-Urtreger A, Göldner FM, Saeki M, Lorenzo I, Goldberg L, De Biasi M, Dani JA, Patrick JW, Beaudet AL (1997) Mice deficient in the $\alpha 7$ neuronal nicotinic acetylcholine receptor lack $\alpha$-bungarotoxin binding sites and hippocampal fast nicotinic currents. J Neurosci 17:9165-9171.

Pappas BA, Bayley PJ, Bui BK, Hansen LA, Thal LJ (2000) Choline acetyltransferase activity and cognitive domain scores of Alzheimer's patients. Neurobiol Aging 21:11-17.

Paxinos G, Watson K (2003) The mouse brain in stereotaxic coordinates, Ed 2. San Diego: Academic Press.

Paylor R, Nguyen M, Crawley JN, Patrick J, Beaudet A, Orr-Urtreger A (1998) Alpha7 nicotinic receptor subunits are not necessary for hippocampaldependent learning or sensorimotor gating: a behavioral characterization of Acra7-deficient mice. Learn Mem 5:302-316.

Perry EK, Tomlinson BE, Blessed G, Bergmann K, Gibson PH, Perry RH (1978) Correlation of cholinergic abnormalities with senile plaques and mental test scores in senile dementia. Br Med J 2:1457-1459.

Pettit DL, Shao Z, Yakel JL (2001) $\beta$-Amyloid - $_{1-42}$ peptide directly modulates nicotinic receptors in the rat hippocampal slice. J Neurosci 21:RC120(1-5).

Poling A, Morgan-Paisley K, Panos JJ, Kim EM, O’Hare E, Cleary JP, Lesné S, Ashe KH, Porritt M, Baker LE (2008) Oligomers of the amyloid-beta protein disrupt working memory: confirmation with two behavioral procedures. Behav Brain Res 193:230-234.

Ren K, King MA, Liu J, Siemann J, Altman M, Meyers C, Hughes JA, Meyer EM (2007) The alpha7 nicotinic receptor agonist $4 \mathrm{OH}-\mathrm{GTS}-21$ protects axotomized septo-hippocampal cholinergic neurons in wild-type but not amyloid-overexpressing transgenic mice. Neuroscience 148:230-237.

Riekkinen PJ, Laulumaa V, Sirviö J, Soininen H, Helkala EL (1987) Recent progress in the research of Alzheimer's disease. Med Biol 65:83-88.

Rogers JL, Kesner RP (2004) Cholinergic modulation of the hippocampus during encoding and retrieval of tone/shock-induced fear conditioning. Learn Mem 11:102-107.

Sanders MJ, Wiltgen BJ, Fanselow MS (2003) The place of the hippocampus in fear conditioning. Eur J Pharmacol 463:217-223.

Savage MJ, Lin YG, Ciallella JR, Flood DG, Scott RW (2002) Activation of c-Jun N-terminal kinase and p38 in an Alzheimer's disease model is associated with amyloid deposition. J Neurosci 22:3376-3385.

Scali C, Giovannini MG, Bartolini L, Prosperi C, Hinz V, Schmidt B, Pepeu G (1997) Effect of metrifonate on extracellular brain acetylcholine and object recognition in aged rats. Eur J Pharmacol 325:173-180.

Søderman A, Thomsen MS, Hansen HH, Nielsen EØ, Jensen MS, West MJ, Mikkelsen JD (2008) The nicotinic alpha7 acetylcholine receptor agonist ssr 180711 is unable to activate limbic neuronsin mice overexpressing human amyloid-beta1-42. Brain Res 1227:240-247.

Spires TL, Meyer-Luehmann M, Stern EA, McLean PJ, Skoch J, Nguyen PT, Backsai BJ, Hyman BT (2005) Dendritic spine abnormalities in amyloid precursor protein transgenic mice demonstrated by gene transfer and intravital multiphoton microscopy. J Neurosci 25:7278-7287.

Stein TD, Johnson JA (2002) Lack of neurodegeneration in transgenic mice overexpressing mutant amyloid precursor protein is associated with increased levels of transthyretin and the activation of cell survival pathways. J Neurosci 22:7380-7388.

Sweatt JD (2001) The neuronal MAP kinase cascade: a biochemical signal integration system subserving synaptic plasticity and memory. J Neurochem 76:1-10.

Taglialatela G, Hogan D, Zhang WR, Dineley KT (2009) Intermediate- and long-term recognition memory deficits in Tg2576 mice are reversed with acute calcineurin inhibition. Behav Brain Res 200:95-99.

Tapiola T, Pirttilä T, Mikkonen M, Mehta PD, Alafuzoff I, Koivisto K, Soininen $\mathrm{H}$ (2000) Three-year follow-up of cerebrospinal fluid tau, betaamyloid 42 and 40 concentrations in Alzheimer's disease. Neurosci Lett 280:119-122.

Teaktong T, Graham A, Court J, Perry R, Jaros E, Johnson M, Hall R, Perry E (2003) Alzheimer's disease is associated with a selective increase in alpha7 nicotinic acetylcholine receptor immunoreactivity in astrocytes. Glia 41:207-211.

Thatcher GR, Bennett BM, Reynolds JN (2006) NO chimeras as therapeutic agents in Alzheimer's disease. Curr Alzheimer Res 3:237-245.

Tomic JL, Pensalfini A, Head E, Glabe CG (2009) Soluble fibrillar oligomer levels are elevated in Alzheimer's disease brain and correlate with cognitive dysfunction. Neurobiol Dis 35:352-358.

Venkitaramani DV, Chin J, Netzer WJ, Gouras GK, Lesne S, Malinow R, Lombroso PJ (2007) $\beta$-Amyloid modulation of synaptic transmission and plasticity. J Neurosci 27:11832-11837.

Walsh DM, Klyubin I, Fadeeva JV, Cullen WK, Anwyl R, Wolfe MS, Rowan MJ, Selkoe DJ (2002) Naturally secreted oligomers of amyloid beta protein potently inhibit hippocampal long-term potentiation in vivo. Nature 416:535-539.

Walsh DM, Klyubin I, Shankar GM, Townsend M, Fadeeva JV, Betts V, Podlisny MB, Cleary JP, Ashe KH, Rowan MJ, Selkoe DJ (2005) The role of cell-derived oligomers of Abeta in Alzheimer's disease and avenues for therapeutic intervention. Biochem Soc Trans 33:1087-1090.

Wang HY, Stucky A, Liu J, Shen C, Trocme-Thibierge C, Morain P (2009) Dissociating $\beta$-amyloid from $\alpha 7$ nicotinic acetylcholine receptor by a novel therapeutic agent, S 24795, normalizes $\alpha 7$ nicotinic acetylcholine and NMDA receptor function in Alzheimer's disease brain. J Neurosci 29:10961-10973.

Watanabe T, Yamagata N, Takasaki K, Sano K, Hayakawa K, Katsurabayashi S, Egashira N, Mishima K, Iwasaki K, Fujiwara M (2009) Decreased acetylcholine release is correlated to memory impairment in the Tg2576 transgenic mouse model of Alzheimer's disease. Brain Res 1249:222-228.

Wenk GL, McGann-Gramling K, Hauss-Wegrzyniak B (2004) The presence of the $\mathrm{APP}$ (swe) mutation in mice does not increase the vulnerability of cholinergic basal forebrain neurons to neuroinflammation. Neuroscience 125:769-776.

Westerman MA, Cooper-Blacketer D, Mariash A, Kotilinek L, Kawarabayashi T, Younkin LH, Carlson GA, Younkin SG, Ashe KH (2002) The relationship between $A \beta$ and memory in the Tg2576 mouse model of Alzheimer's disease. J Neurosci 22:1858-1867.

Wilcock DM, Gordon MN, Morgan D (2006) Quantification of cerebral amyloid angiopathy and parenchymal amyloid plaques with Congo Red histochemical stain. Nat Protoc 1:1591-1595.

Williams B, Granholm AC, Sambamurti K (2007) Age-dependent loss of NGF signaling in the rat basal forebrain is due to disrupted MAPK activation. Neurosci Lett 413:110-114.

Winters BD, Saksida LM, Bussey TJ (2008) Object recognition memory: neurobiological mechanisms of encoding, consolidation and retrieval. Neurosci Biobehav Rev 32:1055-1070.

Yu L, Edalji R, Harlan JE, Holzman TF, Lopez AP, Labkovsky B, Hillen H, Barghorn S, Ebert U, Richardson PL, Miesbauer L, Solomon L, Bartley D, Walter K, Johnson RW, Hajduk PJ, Olejniczak ET (2009) Structural characterization of a soluble amyloid beta-peptide oligomer. Biochemistry 48:1870-1877. 